DOI: $10.19195 / 0137-1150.163 .40$

\title{
DAGMAR MOCNÁ
}

Univerzita Karlova v Praze, Republika Czeska

dagmar.mocna@volny.cz

\section{Lyrický zápisník stárnoucího muže. Prosté motivy Jana Nerudy}

Nerudovy Prosté motivy nebývají čteny jako básně o stárnutí a smrti. Tyto motivy se tu sice objevují, ale jsou vykladači vnímány jen jako součást ústředního tématu souvislosti lidského bytí s věčným koloběhem př́rody. ${ }^{1}$ A přece to bylo právě téma stárnutí, jež stálo u zrodu této sbírky.

Její zárodečnou verzí byly lyrické básně porůznu otiskované v průběhu roku 1879. Autor je od počátku prokazatelně vnímal jako celek, nebot' je při publikování opatřoval souhrnným titulem Prosté motivy. Lyrický mluvčí je stylizován jako stárnoucí muž uvažující o tom, co pro lidského jedince tato fáze života znamená, jak se vyrovnat s nenávratností prožitých životních etap a s omezeností životních perspektiv na prahu stáŕí.

Toto tematické zaměření až nápadně koresponduje s autorovou tehdejší osobní situací, kdy byl ve svých 45 letech zaskočen projevy zdravotních obtíží, jež jej se sílící intenzitou budou doprovázet po celý zbytek života. Krátká spojení mezi autorovým životem a jeho dílem bývají ošidná, nicméně jak jinak si vysvětlit, že Neruda navzdory celoživotní animozitě vůči osobní lyrice náhle začal psát cyklus básní na vysloveně intimní téma. ${ }^{2}$

${ }^{1}$ Takto sbírku vnímala jak dobová kritika, tak pozdější vykladači. Např. jeden ze soudobých recenzentů Otakar Mokrý vystihl myšlenkový koncept sbírky následovně: „Básník sleduje postup hry, kterou příroda provádí věčně stejným, ale též věčně zajímavým svým způsobem před našimi zraky.” O.M. (= Otakar Mokrý), Prosté motivy od Jana Nerudy „Květy” 5, 1883, č. 6, s. 743.

2 Ostatně potvrzuje to sám v dopise Ladislavu Quisovi: „Před 25 lety, když mně přátelé vyčítali, že nemám lyrického citu, odpověděl jsem: »Počkejte, však já také budu psát lyriku, až zestárnu.« Ani jsem nevěděl, jak divnou pravdu pronáším, třeba jsem měl slova ta v duchu dobře motivována. A ejhle, stáří ještě nepřišlo, přišla ale choroba a cit dostal vrch.” (J. Neruda, Básně II, Praha 1956, s. 373). 
Již v prvních dvou časopiseckých ukázkách ze vznikajícího cyklu se objevují všechny základní reakce lyrického subjektu na proces stárnutí; v dalším vývoji budou autorem rozvíjeny, variovány, některé z nich i marginalizovány, nicméně základ této tematické linie budoucí sbírky zůstane týž.

$Z$ dobového hlediska byl patrně nejkontroverznější přesvědčení stárnoucího lyrického subjektu, že má ještě nárok na lásku, chápanou nadto v ryze erotické rovině, de facto jako nezávazný sex s mladou dívkou. ${ }^{3}$ Prudérnost byla Nerudovi odjakživa cizí a od mládí měl s tímto postojem problémy. Což teprve když v Prostých motivech deklaroval právo na erotiku pro toho, kdo by se ve svém věku měl těšit $\mathrm{z}$ dětí, či dokonce vnoučat, bilancovat prožitý život a pomalu se smiřovat s jeho konečností. Nerudův hrdina je v tomto směru provokativně jiný; jak př́ípadně poznamenal František Václav Krejčí, Neruda vnáší do české literatury „lyriku obstárlého garcona”, který si „,chutě ještě chvílemi zahřeší a poslední sladké plody trhá ze stromu života"4; známý modernistický kritik v tom spatřoval významnou Nerudovu inovaci, a to nejen z hlediska české literatury.

Provokativnost tohoto postoje Neruda ještě vystupňoval blasfemickými prvky. Lyrický subjekt „umírající láskou” vyzývá svou milou, aby mu připravila hrob „na své postýlce” a aby jej místo borových tříštěk vystlala svými zlatými vlasy: „Však vdova ty žíti nemůžeš, / nuž ulehni ve hrob ke mně, / a bůh nám dej sladce spočinout a lehká nám budiž země." 5 Se smrtí se tu tedy prozatím žertuje, rakev je zaměněna za milostné lože, a intimní spojení je doprovozeno parafrází pohřební formule.

V úvodní časopisecky otištěné sérii básní se objevila ještě jedna originální reakce lyrického subjektu na proces vlastního stárnutí: nasazení strnulé masky mrzoutského misogyna, alergického na mládí, symbolizované př́íchodem jara. $\mathrm{S}$ „binoklem na očích” a holí v ruce kráćí „květnatým dolem”, a znechuceně pozoruje skotačení „hošíků s nezralými boky” kolem „děvčátek”6 bez stínu porozumění pro jejich jarní touhy. Jde o stylizaci až karikaturně nadsazenou, což poněkud ruší charakter původního cyklu jako básnického zápisníku a vzbuzuje otázku, do jaké míry je skutečným lyrickým deníkem, zrcadlícím Nerudovy tehdejší životní pocity, a do jaké míry byl takto pouze stylizován. Nicméně tato karikaturně deformující stylizace se už v dalších básních cyklu nevyskytuje. Neruda se k ní vrátil až při práci na knize a teprve tehdy dostatečně zhodnotil její nemalý výpovědní potenciál. S touto stylizací do sbírky pronikla nebásnická př́izemnost. V čísle 3 oddílu Jarní (Ted'v zrcadlo hledím a sobě v zrak) se lyrický subjekt, pozorující v zrcadle svůj zchátralý zevnějšek, velmi nepoeticky přirovnává $\mathrm{k}$ zaprášenému, moly prožranému a z módy vyšlému zimníku. V čísle 6 (Kde jsem se to octnul! Veřejné ve zahradě) je (byt' nedůsledně) dekonstruováno sentimentální

${ }^{3}$ F.X. Šalda případně prohlásil, že láska pro Nerudu neznamená cit, ale jen a jen sex (F.X. Šalda, Neruda poněkud nekonvenční, „Šaldův zápisník” VI, 1933-1934, s. 329.)

${ }^{4}$ F.V. Krej, Jan Neruda. Studie jeho vývoje a dila, Praha 1902, s. 137-138.

5 J. Neruda, Básně II, Praha 1956, s. 143.

${ }^{6}$ Ibidem, s. 118. 
pojetí dítěte a místo něho je nabídnuta stylizace „herodesovská”. Jde o básně svou civilní poetikou, založenou na banálních příměrech a sebeironii, zcela nevšední, vpravdě moderní, připomínající dikci Macharovy prvotiny Confiteor (ta ostatně vyšla jen o čtyři roky později).

Přestože se v básních objevují přírodní motivy spojené se všemi ročními obdobími, nejzřetelněji se lyrický subjekt identifikuje s podzimem, což potvrzuje dominantní pozici tématu stárnutí v této nejstarší textové vrstvě sbírky. Ovšem takovým, jenž je ještě plný barevné krásy a síly a rozhodně neznamená začátek loučení se životem. Jeho symbolem se stává personifikovaný Boubín, ${ }^{7}$ táta od rodiny, dobrosrdečně se chechtající kouskům, jež vyvádějí jeho synkové. ${ }^{8}$ Naopak pozdní podzim, nabývající podoby nemohoucího starce, je lyrickým subjektem rázně odmítnut ( $V$ šak nechtěl bych být jak ten podzimek, Podzimní, číslo 9).

Autor nemilosrdně líčí fyzickou zchátralost antropomorfizovaného pozdního podzimu: v očích má zákal, popadá dech, a když jde, „krok chrastí, jak suchá když mu kůže se flandá kol kostry"; ; poprvé se tu objevuje slovo „stařec”, jednoznačně implikující konečnou fázi života. Neruda ovšem v žádném případě nechce vyvolávat čtenářův soucit (v tom se jeho postoj zásadně liší od rané básně Před fortnou milosrdných, rovněž s ústřední figurou starce, líčeného tam ovšem bez odpudivých fyziologických detailů). Byt' je to proti všem tradičním hodnotovým očekáváním, lyrického subjektu se při pohledu na zuboženou stařeckou fyzis zmocňuje intenzivní pocit trapnosti (,když k zlosti se krev chce mu rozvařit, je vášeň ta jenom už $\mathrm{k}$ smíchu"10). Takovéto podoby stáŕí se lyrický subjekt $\mathrm{v}$ žádném případě nechce dožít, a proto si v pozdějších básních na toto téma přeje smrt na vrcholu sil fyzických i tvůrčích. ${ }^{11}$ Na představě vlastní stařecké nemohoucnos-

${ }^{7}$ Motiv Boubínu by mohl svědčit pro autobiografické podloží cyklu, nebot' právě tento vrch je dominantou šumavského panoramatu díváme-li se na ně z Vlachova Březí, místa Nerudových letních pobytů v rodině bratrance Tichého, zpestřených dívčím půvabem jeho dcery Aničky, jež bývá biograficky orientovanými vykladači považována za inspirátorku milostných čísel Prostých motivư.

${ }^{8}$ Originální plebejskost této personifikace se ovšem nesetkala s pochopením u Františka Zákrejse, jenž báseň nazval „,nedosti veselým žertem” (F. Zákrejs, Nové pisemnictví, „Osvěta” 14, 1884, č. 1, s. 71.) Jeho odmítavá reakce svědčí o síle parnasistních norem, jež by v př́ipadě popisu této šumavské hory bezesporu upřednostnily obdiv nad její majestátností, vyjádřený patřičně vznešenou dikcí. Tyto normy se bezesporu projevily i v nelibosti Emanuela Miřiovského vůči čísle 5 oddílu Jarní, v němž se lyrický subjekt, stylizovaný jako stárnoucí misogyn, nevybíravě vyjadřuje o povykujících dětech jako o „lidském smetí”. Takovéto „drsnosti” „rádi nevidíme ani u Nerudy”, komentuje to Miřiovský (E. Miřiovský, Prosté motivy, „Lumír” 11, 1883, č. 14, s. 224.)

9 J. Neruda, op. cit., s. 159.

10 Ibidem.

11 O naléhavosti tohoto tématu svědčí skutečnost, že se k němu vracel opakovaně; ještě ve 2. rozšířeném vydání se objevuje nová báseň s podtitulem Vzpomínka na Hálka, končící verši: „musí to přece být pěkné jen, když člověku prchnou dny poslední / tak v plničké záŕi, tak v spěchu!" (ibidem, s. 145.) 
ti ho více než možný výsměch sužuje představa blahosklonného soucitu okolí, se zaujetím pozorujícího jeho postupné chátrání: „Chudáček už klesá — klesá.”12

Skutečnosti, že s problematikou stáří souvisí téma zániku, si byl Neruda pochopitelně vědom, ale zpočátku se ho dotýkal spíše v souvislosti s prrírodními jevy (Stará vrba) anebo bez vazby k procesu stárnutí (smrt nemluvněte v básni s časopiseckým titulem Motiv zimni).

Naplno rozvinul téma smrti ve dvou básních, publikovaných na sklonku roku 1880, po téměř roční přestávce, kdy na Prostých motivech nepracoval. ${ }^{13}$ Publikoval je pod souhrnným názvem Motivy z pozdního podzimu, poprvé tedy, byt' obrazně, propojil téma zániku s tématem stárnutí — a poprvé se smrt týká přímo lyrického subjektu. Básník tu jde na dřeň bezprostředního prožitku, jehož intenzitu nehodlá ničím marginalizovat. Je to vpravdě moderní lyrika, vynikající výrazovou úsporností a autenticitou. První báseň nese poklidný, takřka biedermeierovský název Vycházka, avšak útržkovitá dikce (báseň začíná nezvykle krátkými dialogickými replikami s množstvím otazníků, vykřičníků a pomlček), reportážní prézens a až hysterická reakce lyrického subjektu (,vyndám zrcátko”, „let' ke všem čertům jen! Již o strom sklo se drtí"14) svědčí o tom, že ve skutečnosti jde o panický útěk před smrtí, jíž ovšem utéci nemůže, nebot' si ji nosí v sobě, jak se přesvědčuje při pohledu do zrcátka, odrážejícího „toilettu smrti”. Ve druhé básni už lyrický subjekt — nemocný a všemi opuštěn — odevzdaně čeká na její př́ichod. Jediným společníkem je mu noční lampa, svítící „,by liják znal, kam mráz svůj lít, / by kulich zřel, kam v okno bít, / a smrt by nezbloudila."15

Zde vlastně Neruda ve svém lyrickém deníku došel až na konec ${ }^{16}$ - lyrický subjekt je na pokraji smrti, očekává ji a děsí se jí zcela živočišně. Nedostává se mu žádné náboženské útěchy ani lidské podpory, svůj konec si bude muset protrpět sám.

Kdyby takto celý cyklus skončil, předznamenával by tvorbu básníků moderny; Neruda by se stal průkopníkem poezie založené na autentické osobní výpovědi bez jakýchkoli alegorických či jiných filtrů. Jak ovšem ukazuje další etapa geneze Prostých motivi̊, toto řešení bylo pro něho nepřijatelné. Navzdory své blízkosti budoucí moderně (jež jej také nikoli náhodou poprvé docení jako básníka) nesledoval ideál poezie jako intenzivní osobní zpovědi, nýbrž — ve shodě s představami ruchovsko-lumírovské generace — jako mediátora obecně platných hodnot. Nadto míra sebeobnažení, k níž v oněch dvou básních o smrti

12 Ibidem, s. 173. Bezesporu šlo o problém hluboce autobiografický. Smrt v plné síle, po níž touží lyrický subjekt Prostých motivi̊, nebyla Nerudovi dopřána. Jeho eruptivní básnické renouveau skončilo roku 1883, přičemž žil ještě dalších 7,5 roku, aniž psal něco podstatnějšího než pravidelné nedělní fejetony kolísavé úrovně (tento každodenní horizont překročilo jen několik básní, byt' vesměs vynikajících).

13 Jde o číslo 10 oddílu Podzimni a číslo 13 oddílu Zimní.

14 Ibidem, s. 160.

15 Ibidem, s. 178.

16 Vodička: „Nerudova sbírka dostala nové rysy, podnícené novou životní zkušeností a jeho nemocí. To ovšem oddálilo její dotvoření." (ibidem, s. 372.) 
dospěl, v kontextu soudobé literatury nebývalá, odporovala Nerudovu celoživotnímu přesvědčení o tom, že intimní traumata do poezie nepatří, nebot' ta se má vyslovovat $\mathrm{k}$ relevantnějším tématům, důležitým pro rozvoj národa a lidstva. ${ }^{17}$ To mu však jeho tehdejší osobní situace zřejmě neumožňovala, a patrně i proto se lyrik Neruda na další rok a půl odmlčel (a svou poraněnou senzibilitu léčil epikou Balad a romancí).

K Prostým motivưm se vrátil až v létě 1882 , a tehdy už podle všeho s intencí dotvořit lyrický cyklus z roku 1879 v knihu. To ovšem znamenalo zásadně změnit jeho charakter, nebot' časopisecká a knižní publikace měly v tehdejší literatuře odlišný status. Byl-li periodický tisk základnou běžného literárního provozu, knižní tituly byly stupně na Parnas. Neruda ve všech svých knihách usiloval o maximální komplexnost zpracování zvoleného tématu, zároveň však také — v souvislosti se svou představou moderního čtenáře, jenž chce být neustále překvapován něčím novým ${ }^{18}$ - o pestrost a rozmanitost.

Ve světle těchto postulátů je zřejmé, že lyrický cyklus založený na tématu stárnutí a podzimní náladě byl pro sbírku př́liš jednostrunný a — vzhledem k výše vzpomenutému Nerudovu názoru na intimní lyriku — rovněž nemístně subjektivní. Pro knižní prezentaci bylo tudíž třeba subjektivitu cyklu potlačit ${ }^{19}$ a naplnit sbírku méně osobním, o to však reprezentativnějším obsahem.

Myšlenkovým a kompozičním rámcem sbírky se stal princip střídání ročních období, koncept s úctyhodnou literární tradicí sahající až k antice. ${ }^{20}$ Tím byla potlačena intimita původního cyklu, protože osobní situace lyrického subjektu se stala synekdochou obecného lidského údělu. Prosté motivy tak dostaly filozofický rozměr, jejž původní lyrický cyklus neměl (navázaly na tázání Písní kosmických po limitech lidské existence a její situovanosti v rádu př́rody). ${ }^{21}$

17 Již v recenzi Večerních písní svého souputníka a zároveň konkurenta Vítězslava Hálka vyjádřil požadavek, aby básník „nezpíval jen, co on jakožto individuum cítí, ale co každý s ním zároveň cítiti musí." (J. Neruda, Literatura I, Praha 1957, s. 48).

18 Vyjádřil ji ve stati Moderní člověk a umění z r. 1867.

19 Nicméně i po všech odosobňujících zásazích cítil Neruda nad Prostými motivy rozpaky a stud; jako by šlo o básnický poklesek, jejž může omluvit jen jeho špatný zdravotní stav. Vyjádření tohoto typu najdeme v dopisech Ladislavu Quisovi i Vratislavu Kazimíru Šemberovi. Prvnímu z nich napsal 17.4.1883: „Písně kosmické [...] mají obsah, do kterého každému čtenáři něco je, jsou objektivní; Prosté motivy jsou ale subjektivní: do toho, co je v nich, není vlastně nikomu nic než mně." (J. Neruda, Básně II..., s. 373.)

${ }^{20}$ J. Peterka, Kalendářni cyklus, [w:] Poetika české meziválečné literatury, Praha 1987, s. 178.

${ }^{21} \mathrm{O}$ tom, že se Nerudovi v očích soudobé kritiky (a předpokládejme, že i čtenářů) tento zásadní obrat od intimity k obecnosti podařil, svědčí výklad autorovy intence z pera Otakara Mokrého, považujícího za zásadní impuls k napsání sbírky autorovo pozorování př́rody, a teprve až sekundárně také vlastního nitra: „úkazy přírodní upoutaly v hlubší své podstatě pozornost básníkovu; zamyslil se nad nimi a sám nad sebou”. O.M. (= Otakar Mokrý), Prosté motivy..., s. 743. Podobně František Zákrejs konstatuje: „Př́roda koná v Prostých motivech svou básnickou povinnost, obrazíc specielně básníkovo, a tím také všeobecně lidské nitro." (F. Zákrejs, Nové pisemnictví..., s. 71.) 
Předpolím pro uskutečnění této rámcové ideje byla v původním cyklu hojně se vyskytující konfrontace pocitů lyrického subjektu s aktuálním př́ŕrodním děním; nyní ovšem bylo třeba rozpracovat tento princip pro všechna roční období. V původním lyrickém cyklu se vedle dominantního podzimu nejvýrazněji rýsoval oddíl Letní jako žhavě erotická chvála životních radostí. Nejvíce nesnází měl Neruda s oddílem Jarní, jistě i proto, že to bylo období, jež mu bylo vzhledem k jeho „podzimnímu” věku nejvzdálenější, ale hlavně kvůli otřelosti této básnicky velmi frekventované tematiky; obtíže psaní o jaru Neruda reflektoval v sérii fejetonů z let 1883-1884, obsahující i parodické „,básně na jaro”, je tedy zřejmé, že si toho byl dobře vědom. Neruda sice $\mathrm{v}$ tomto oddílu rozvinul originální mrzoutskou stylizaci lyrického subjektu, naznačenou již v jedné z nejstarších básní původního cyklu, nicméně i tak v oddílu Jarní nalezneme nejvíce básní pohybujících se na úrovni běžné dobové poezie (např. Bud' požehnán, ty lístku první, s verši jako ,a je mně ted', jak vzduch by nesl/ na vlažných vlnách bájné hlasy, / jak po slunce by zlatých prškách/ se třepotaly dávné časy." ${ }^{22} \mathrm{Na}$ druhou stranu se tu objevuje neobyčejně svěží číslo 11 (Hej, uvidiš prrirodo, uvidišs) s typicky nerudovským lyrickým hrdinou, bezstarostně kráčejícím přírodou a pohvizdujícím s okouzlující nonšalancí „odrhovačku” na svinutý růžový lístek. ${ }^{23}$

Lyrický subjekt přitom ztratil konkrétní věk. Ve sbírce sice zůstaly básně, jež hovoří o jeho prošedivělých vlasech a dalších projevech stárnutí, ale zejména nově připsané básně jsou z tohoto hlediska indiferentní. Představu o věku lyrického subjektu si pak čtenář odvozuje z jeho momentálních reakcí: na jaře mladistvě hravých, $v$ létě mužně rozhořelých, na podzim rozvážných a v zimě stařecky nemohoucích. Dynamika těchto mentálních proměn lyrického subjektu zastírá skutečnost, že jde pořád o muže v podzimní etapě života. ${ }^{24}$ Tato výchozí situace původního lyrického cyklu je $\mathrm{v}$ definitivní podobě sbírky zatlačena do pozadí a v důsledku toho se také marginalizuje původně dominantní téma stárnutí.

Oslabení původní subjektivity se projevilo mimo jiné v postoji lyrického subjektu k jednotlivým ročním obdobím; ten je v knize standardnější než v původním cyklu. Nejvýrazněji se to týká erotiky, jíž je tu na rozdíl od původního cyklu vyhrazeno léto; ${ }^{25}$ do značné míry tím zmizela původní provokativnost, ${ }^{26}$ kdy byly nejžhavější erotické verše přisouzeny stárnoucímu muži; stále tu však zůstává nekonvenční důraz na př́močarou sexualitu, jež kupodivu recenzentům

22 J. Neruda, Básně II..., s. 126.

23 Ibidem, s. 127.

24, ,[D]o tematického rámce jediného roku vtěsnává intimně laděný obraz celého běhu lidského života od mládí přes dospělost a stáří až ke smrti.” J. Peterka, op. cit., s. 179.

${ }^{25}$ Neruda tak učinil navzdory tomu, že v básni s incipitem Nesmějte se pavučince (Letní, číslo 7) výslovně mluví v souvislosti s šedinami lyrického subjektu o podzimu a prrírodních jevech pro něho typických. Tyto motivy jsou však účinně marginalizovány žhavě letním kontextem okolních básní.

${ }^{26}$ Blasfemicky laděné číslo 9, pohrávající si se záměnou rakve s milostným ložem, bylo v knižní verzi nově opatř̌eno distancujícím podtitulem Motiv cizí. 
nepřipadala nijak skandální (je zřejmé, že v tomto směru se ve srovnání s Nerudovými počátky český literární prostor liberalizoval, jistě i díky vlivu francouzské kultury, z domácí tvorby pak napřr. díky erotické lyrice Vrchlického, podstatně ovšem delikátnější než Nerudův plebejský hédonismus.

$\mathrm{Na}$ druhou stranu je ovšem třeba říci, že erotické žhavosti v knize celkově neubylo, naopak spíše přibylo; nekonvenčně je tu erotizována i příroda (způsobem připomínajícím pozdější vitalismus). V básni s incipitem Náš kraj se ženil dnes (číslo 6 oddílu Letní) je bouřka vylíčena jako oplodňující akt mezi krajem a oblohou, po jehož dokonání se objevuje duha ,jak vínku zdoba vpůli roztržená" ${ }^{27}$ a pole voní předzvěstí budoucího chleba; znovu se tím potvrzuje Nerudův přímočaře fyziologický pohled na lásku, která je u něho bezprostředně spojena se sexem a ten pak s plozením. Erotický podtext má i hédonismus, s nímž si lyrický subjekt užívá letního tepla a slunce („tělem sladké teplo běží, jak když děva v rty mne líbá" ${ }^{28}$ ). Tuto afinitu k fyzickým rozkoším (kdy není valného rozdílu mezi milováním a vyhříváním se na slunci) přitom Neruda obhajuje jako elementární hodnotu lidské existence: „Tak vesele se to vandruje, / ve uzlíčku hřích dědičný - / ach bez hříchu by ten květný svět / již zpola tak nebyl sličný!"29 Fakt, že tyto básně letní blaženosti vznikaly až v době Nerudovy vzrůstající fyzické nemohoucnosti (a nadto patrně v zimě), upozorňuje na problematičnost prrímočaře biografického čtení sbírky.

Na definitivní knižní podobu Prostých motivů měla vliv ještě jedna okolnost: Neruda tu více než v původním lyrickém cyklu respektuje soudobé básnické normy. Literární situace, do níž svými zralými básnickými sbírkami (počínaje Pisněmi kosmickými) vstupoval, se totiž podstatně lišila od dob jeho začátku. Tehdy to byl on, kdo se svými vrstevníky spoluurčoval podobu moderní poezie; poté, co se na více než deset let jako básník odmlčel (a poté, co nečekaně zemřel Hálek), se iniciativy v tomto směru chopila nastupující ruchovsko-lumírovská generace, jež záhy vyplnila prostor uvolněný májovci. Poetika této generace byla přitom v mnohém té Nerudově protikladná, byt'v jeho tvorbě najdeme vedle převládající výrazové prostoty rovněž košatou básnickou dikci (ne náhodou připomíná jeden z dobových recenzentů Prostých motivů Nerudovu ranou skladbu $O$ Šimonu Lomnickém jako př́iklad Nerudova slovesného umění, evidentně konvenujícího dobovému vkusu více než jiné autorovy opusy). ${ }^{30}$ Již Písně kosmické ukázaly, že Neruda dokázal vstřebat mnohé z parnasistních tvůrčích postupů, a to většinou nikoli ke škodě věci. A ani Prosté motivy nejsou tak zcela „prosté”, jak avizuje jejich název.

Širokodechou deskriptivností, příznačnou pro básnické skladby ruchovsko-lumírovské generace, disponují dvě nově připsané básně líčící atmosféru léta (Slunce je jak velký žernov, Náš kraj se ženil dnes). Ovšem přinejmenším klíčový

27 J. Neruda, Básně II..., s. 140.

${ }^{28}$ Ibidem, s. 138.

${ }^{29}$ Ibidem, s. 142.

30 E. Miřiovský, op. cit., s. 224. 
obraz první z nich („Slunce je jak velký žernov, pánbíček jím den svůj mele”31) je podstatně modernější než opulentní perifrastičnost Svatopluka Čecha či metaforika Jaroslava Vrchlického; charakterem obrazné konstrukce prripomíná spíše o čtyři básnické generace mladšího Jiřího Wolkera (viz incipit básně Žně „Slunce je veliký básník / a napsalo krásnou báseň / zlatým perem / na naši zem"32.

Estetickými normami parnasismu jsou nejvíce ovlivněny nově připsané básně o smrti. Neruda se už nevrací k naléhavé dikci básní z roku 1880, naopak usiluje o maximální eufemizaci. Obraz náhlého podtětí života ve vstupní básni oddílu Letni (Již lučina je zkosena) není spojen s děsem, samotou a nemocí, jako v básních z roku 1880, ale s vůní pokosené trávy a písní, byt' nedozpívanou. Ještě dekorativněji je téma smrti pojato $\mathrm{v}$ parnasistně laděné básni Já hnal se pestrým, luzným za motýlem (jediném pro knihu připsaném čísle oddílu Podzimni), v níž lyrický subjekt nachází v těsné blízkosti „sněžné parnasie” můru smrtonošku „s umrlčí lebkou ve svém vazu." 33 Tato formalistická alegorická hř́čka není nijak spojena s konkrétní situací lyrického subjektu, a zanechává tudíž čtenáře - na rozdíl od intenzivních básní z roku 1880 — v duševním klidu. Je nepochybné, že uvedená eufemizace, pro dnešního čtenáře př́liš literátsky neživotná, harmonovala s očekáváním tehdejších čtenářů i kritiky. Je to zřejmé z toho, jaké kvality recenzenti na Nerudově poezii nejvíce oceňovali: „rozkošný půvab,”34 „tryskající rozmar" ${ }^{35}$ a „rozmilou jímavost,", 36 z negativních pocitů byl pro ně akceptovatelný snad jen „,dojemný jakýsi elegický př́́dech," ${ }^{37}$ naproti tomu autentickou hrůzu ze smrti, artikulovanou v básních z roku 1880, vnímal soudobý recenzent jako nepř́ípadnou ,drsnost." 38

V duchu parnasistních norem pojednal Neruda také explicit, v němž se v logice celkového konceptu sbírky střetá nekonečnost př́rodního cyklu s konečností lidského života. Účinným anestetikem se tu znovu stal princip alegorie, jenž odsunul téma smrti do bezpečné vzdálenosti od lyrického subjektu: jeho skon je tu líčen jako rozpad korábu zasaženého bleskem, a to s rozvinutím vyspělého deskriptivního umění, kladoucího důraz na malebnost a dramatičnost poutavého děje. Na to, že jde o obrazné vylíčení zániku lidského jedince, je čtenář upozorněn až

31 J. Neruda, Básně II..., s. 138.

32 J. Wolker, Zasvěcování srdce (zprac. V. Macura), Praha 1984, s. 30.

33 J. Neruda, Básně II..., s. 151.

34, ,[J]sou řadou rozkošných básní lyrických [...] zamlouvát' se nám každá zvláštním svým půvabem” F.A. Tichý (=František Dlouhý), Poetické besedy, „Literární listy” 4, 1883, č. 11, s. 88.

35 E. Miřiovský, op. cit., s. 224.

${ }^{36}$ F. Zákrejs, op. cit., s. 70. Jako doklad této jímavosti referent uvádí báseň Kde jsem se to octnul!, ovšem př́iznačně nikoli její první, drsně herodesovskou část, nýbrž tu druhou, cituplnou, v níž se staromládenecký lyrický hrdina ptá ,plaše a zajikavě” batolete, jež se s ním přišlo družit: „Dět'átko, máš mne rádo?” (J. Neruda, Básně II..., s. 122.) Je zřejmé, že čtenář soudobé poezie chtěl být ušlechtile dojímán, avšak o ironické rozbíjení básnických klišé nestál.

37 O.M. (= Otakar Mokrý), op. cit., s. 743. Podobně hovoří referent „Světozoru”: „Mnohé básně, zvláště »podzimní« a »zimní«, dojímají nás elegicky.” („Světozor” 17, 1883, č. 19, s. 223.)

38 E. Miřiovský, op. cit., s. 224. 
v posledních dvou verších, jimiž velkolepé mořské divadlo překvapivě vyúst’uje do účinné subjektivní pointy, připomínající hymnický explicit Písní kosmických: „Jen chvíli ještě malou, krátkou chvíli / a popel můj se s širým mořem smísí!”39 Závěrečné dvojverší dojímá svým nepatetickým smířením s lidskou konečností, nicméně není s to neutralizovat odtažitou pompéznost celku, cizí současnému recipientovi, avšak bezesporu vyhovující vkusu čtenáře tehdejšího, odchovaného rétorickým verbalismem ruchovsko-lumírovské poezie. ${ }^{40}$

V jejím duchu získal lyrický subjekt $\mathrm{v}$ několika připsaných číslech nový rys: stal se z něho básník, přesněji řečeno „pěvec”. Tato konvenční autostylizace výrazně oslabila původní autenticitu lyrického subjektu, nicméně v souvislosti s ní do sbírky pronikl nový aspekt námi sledovaného tématu — otázka nesmrtelnosti. V básni s incipitem Když jsem mlád byl (číslo 7 oddílu Zimni) lyrický subjekt vyjadřuje naději, že ,z mých zpěvů mnohý / také přes hrob zvučet bude," ${ }^{41}$ cestou k nesmrtelnosti tedy může být umělecké dílo. ${ }^{42}$ Nicméně Neruda tento směr uvažování o nesmrtelnosti dále nerozpracovává, nabízí totiž jiné řešení: přesáhnout konečnost vlastní existence můžeme zplozením potomstva. Svědčí to o tom, že lyrický subjekt Prostých motivư není prioritně básníkem, nýbrž člověkem a mužem. To, co je pro něj podstatné, se netýká umění, nýbrž života. „Až do těch dob žádný ještě básník český neodvážil se uvésti svou denní skutečnou existenci tak beze všech příkras a líčidla do veršů,” říká o Prostých motivech Krejčí. „Básník nestaví se tu na žádný kothurn, nehraje si na patetického barda, netváŕí se genialně, nenavléká pro chvíle básnění své duši sváteční kabát.” A pokračuje: „V tom ohledu mají Prosté motivy jistý význam revoluční. ${ }^{43}$

39 J. Neruda, Básně II..., s. 179.

${ }^{40}$ Svědčí o tom opět reakce soudobých recenzentů; Emanuel Miřiovský s uspokojením konstatoval, že v závěrečné básni se autor ,probral” z hluboké bolesti předchozího čísla, a to „ne tak obsahem, jako slovesným ulíbezněním drsného akordu" (E. Miřiovský, op. cit., s. 224.). Smrt byla tedy legitimním tématem i v parnasistní poezii, avšak vyžadován byl harmonizující odstup a důraz na eleganci formy. $\mathrm{O}$ tom, že závěrečná alegorická báseň byla spíše úlitbou dobovému vkusu, svědčí skutečnost, že se Neruda k intenzivně minimalistickému stylu dvou básní o smrti $\mathrm{z}$ roku 1880 opakovaně vracel, a to s jednoznačným uměleckým úspěchem. Poprvé v básni otištěné v 2. rozšířeném vydání Prostých motivů (číslo 11 oddílu Podzimni), ličící dojmy z návštěvy vesnického hřbitůvku. Hrůza ze smrti na tomto poklidném místě odplývá, lyrický subjekt se přestává bránit myšlence věčného spočinutí. Druhá byla napsána rok před smrtí a do Prostých motivư se už tudíž nedostala. Klid předchozí básně je tu vystř́íán nervózní atmosférou čekání na příchod smrti: „Smrt zvoní: „Na vůz! Čas je — čas!”; lyrický subjekt už má sbaleno, ale „smrt po sousedstvě hýř́ kdes" a na něho, konečně odhodlaného opustit tento svět, zapomněla. (J. Neruda, Básně II..., s. 192). Vznikla tak obsahově i stylově kompaktní čtveřice básní o smrti, ve sbírce ovšem (patrně záměrně) rozptýlená do různých oddílů, čímž se jejich synergický efekt podstatně oslabil.

41 J. Neruda, Básně II..., s. 172.

42 O tom, že stylizace do „pěvce” a úvahy o nesmrtelnosti básnického díla konvenovaly dobovému, parnasismem ovlivněnému vkusu, svědčí reakce recenzenta Lumíru, jenž básně na toto téma považuje za jedny z nejlepších (E. Miřiovský, op. cit., s. 224). Recenzent Otakar Mokrý ostatně sám Nerudu nazývá „proslulým pěvcem”. O.M. (= Otakar Mokrý), op. cit., s. 743.

${ }^{43}$ F.V. Krejčí, op. cit., s. 136. 
A Jiří Karásek ze Lvovic postavil Prosté motivy do prrímého protikladu s tvorbou Nerudova nejoceňovanějšího básnického současníka: „Všimněte si data vzniku Prostých motivů a uvědomíte-li si, jaká poesie dospívala v letech 1879-1882 svého vrcholu, vzpomenete-li si na grandiosně komponované, efektní, kolosální sádry Vrchlického, tu teprve vám bude možno oceniti v celém dosahu originální notu těchto krátkých písní." 44

Teprve modernističtí kritikové tedy dokázali odhalit a spolu s tím i docenit onu původní intimní rovinu Prostých motivů, překrytou později parnasistním dekorem. Je to podle našeho názoru právě ona, jež činí z prostých motivů pozoruhodné umělecké dílo. Poprvé v české literatuře tu byla tak komplexně a originálně tematizována osobní situace stárnoucího muže, jeho neustávající touha po lásce a sexu, ale zároveň i fyzické chátrání, jež je tu popsáno s nemilosrdnou věcností, a živočišně panický strach ze smrti. Neruda si tu, byt's rozpaky a po dlouhém váhání, dovolil luxus vystoupit na chvíli z role národního barda. Díky této odvaze k sebeobnažení, která mu po celý život spíše chyběla, vytvořil básnickou sbírku, jež na rozdíl od většiny jeho poezie má co říci i dnešnímu čtenáři (projevuje se to např. i výrazným nárůstem ukázek z této sbírky v současných českých čítankách ${ }^{45}$ ): jestliže jeho patetické vlastenectví působí v kontextu dnešních občanských ideálů nezř́́dka jako nepřijatelný šovinismus, stárnutí navzdory moderní medicíně zůstává problémem, s nímž se musí vypořádat každý z nás. Neruda to činí originálně, bez iluzí, přitom však s empatií pro něho tak typickou. Proto jsou Prosté motivy něčím víc než položkou v kánonu české literatury — jsou stále živou uměleckou výpovědí o podstatných stránkách lidského života.

\section{Bibliografie}

Karásek ze Lvovic, J., Jan Neruda, Praha 1910.

Krejčí F.V., Jan Neruda. Studie jeho vývoje a dila, Praha 1902.

Literatura česká, „Světozor” 17, 1883, č. 19 - autor neuveden.

Miřiovský E., Prosté motivy, „Lumír” 11, 1883, č. 14.

Mrázková M., Dílo Jana Nerudy v čitankách, diplomová práce obhájená na Univerzitě Karlově v Praze, Pedagogické fakultě, v roce 2014.

Neruda J., Básně II, Praha 1956.

O.M. (= Otakar Mokrý), Prosté motivy od Jana Nerudy, „Květy” 5, 1883, č. 6.

Peterka J., Kalendářni cyklus, [w:] Poetika české meziválečné literatury, Praha 1987.

Šalda F.X., Neruda poněkud nekonvenční, „Šaldův zápisník” VI, 1933-1934.

Tichý F.A. (= František Dlouhý), Poetické besedy, „Literární listy” 4, 1883, č. 11.

Wolker J., Zasvěcování srdce, zprac. Vladimír Macura, Praha 1984.

Zákrejs F., Nové písemnictví, „Osvěta” 14, 1884, č. 1.

${ }^{44}$ J. K. ze Lvovic, Jan Neruda, Praha 1910, s. 56.

45 Viz bakalářská práce Miroslavy Mrázkové Dílo Jana Nerudy v čitankách, obhájená na Univerzitě Karlově v Praze, Pedagogické fakultě v roce 2014. 


\section{The lyrical diary of the aging man (Prosté motivy by Jan Neruda)}

\section{Summary}

The present article discusses the motif of ageing in the collection of poems Plain Themes (Prosté motivy) by the highly esteemed Czech writer Jan Neruda. The theme of coming to terms with aging is especially apparent in the initial version of the collection - a lyrical cycle of 1879, which centres upon autumn natural motifs, corresponding with the situation of the speaker of the poems (as well as the author himself). Apart from traditional reactions to the aging process (melancholy, recapitulation, sorrow for the bygone youth), we can observe a continuing striving for erotic experience, testifying to the speaker's desire to fully enjoy the remaining time of his life. At the end of the cycle, Neruda attempts at coming to terms with death by means of two powerful poems, conceived as an authentic, almost diary-like account of the horrible sense of the inevitable end.

In the definitive book version of the cycle, the topic of aging is incorporated into a new concept of the collection, which is the confrontation of the linearity of life and the circuitous course of the natural cycle. The reflection upon aging is placed in the "Autumn" section of the collection, whose melancholic and recapitulative character is even more prominent (whereas the erotic themes have been relegated to the "Summer" section). The death of the speaker is conceived in a more distanced way, making use of a rich allegorical apparatus. The book version also introduces the topic of immortality, whose source is not, rather surprisingly, a work of art of everlasting value, but that of procreation. Neruda thus confirms his anti-aesthetical attitude, which makes him stand out in the context of the prevailing Parnassian orientation of Czech poetry of the period.

Keywords: John Neruda, intimate poetry, ageing, calendar cycle, czech poetry of the second half of 19. century

\section{Liryczny dziennik starzejącego się mężczyzny (Prosté motivy Jana Nerudy)}

\section{Streszczenie}

W artykule podjęty został temat starzenia się w zbiorze poezji Prosté motivy autorstwa czołowego czeskiego pisarza Jana Nerudy. Radzenie sobie ze starzeniem jest znaczące zwłaszcza dla źródłowej wersji zbioru — lirycznego cyklu z roku 1879 skupionego wokół jesiennych motywów przyrodniczych korespondujących z sytuacją życiową podmiotu lirycznego (i samego autora). Obok stereotypowych reakcji na proces starzenia się (melancholia, podsumowania, tęsknota za utraconą młodością) spotykamy się tu także z ciągłym pragnieniem erotycznych przeżyć zdradzających chęć cieszenia się w pełni czasem, który pozostał podmiotowi lirycznemu. Pod koniec cyklu Neruda starał się pogodzić z tematem zbliżającej się śmierci za pomocą dwóch sugestywnych wierszy koncypowanych jako autentyczny, niemal dziennikowy opis uczucia strachu przed nieuchronnością przemijania.

W ostatecznej wersji książkowej temat starości został dołączony do nowego konceptu zbioru, którym stała się konfrontacja linearności życia ludzkiego z wiecznym biegiem cyklu natury. Refleksje nad procesem starzenia się włączone są przeważnie do części Jesiennej i, w odróżnieniu od pierwotnego cyklu, podkreślony jest tu element melancholijny i podsumowujący (tematyka 
erotyczna została przesunięta do części Letniej). Śmierć podmiotu lirycznego jest omówiona dość niejednoznacznie, z użyciem potężnego aparatu alegorycznego. W wersji książkowej pojawia się również temat nieśmiertelności. Jej źródłem nie jest dzieło artystyczne, ale spłodzenie potomstwa. Neruda w ten sposób potwierdza swoją antyestetykę, co odróżnia go od dominującej parnasistowskiej orientacji ówczesnej liryki.

Stowa kluczowe: Jan Neruda, poezja intymna, starość, cykl kalendarzowy, czeska poezja drugiej połowy XIX wieku 